\title{
UJI LABORATORIUM DAN LAPANG INSEKTISIDA NABATI BIOPROTEKTOR BP-1 TERHADAP TUNGAU PARASIT Varroa destructor Anderson \& Trueman PADA LEBAH MADU Apis mellifera $\mathrm{L}$.
}

\author{
Laboratory and Field Trials of Bio-Insecticide Bioprotektor BP-1 Against Parasitic Mites \\ Varroa destructor Anderson \& Trueman on Apis mellifera L. Honey Bees
}

\author{
Kuntadi \\ Pusat Penelitian dan Pengembangan Hutan, Kampus Badan Litbang dan Inovasi \\ Jl. Gunung Batu No. 5 Kotak Pos 165 Bogor 16118, Jawa Barat, Indonesia \\ Tlp.: (0251) 8633234; Fax. : (0251) 8638111 \\ Email: kundadi10@yahoo.com \\ *Tanggal diterima: 25 Februari 2016; Tanggal direvisi: 5 Maret 2016; Tanggal disetujui:
}

\begin{abstract}
Bioprotektor BP-1 is a botanical pesticide formulated from clove, lemongrass, and temulawak oils. Previous studies concluded that the pesticide composed of engenol, sitronellal, and xanthorrhizol is the most promising agent to control parasitic mite Varroa destructor compared to several essential oils and bio-insecticides. An experimental research was conductedto determine the effective dose and application method of BP-1 through laboratory and field trials. The efficacy trials in 2 phases followed by application test in the laboratory showed that $10 \%$ concentrations of the bio-insecticide given in a dose of $0.25 \mathrm{ml}$ per liter volume resulted $\mathrm{V}$. destructor mortality rate above $50 \%$ with low rate on honey bee mortality. Field trials indicatedthat $10 \%$ concentration and spray methodwere the most prospective procedure in applying BP-1 to control $\underline{\mathrm{V}}$. destructor in Apis mellifera honey bee colonies.
\end{abstract}

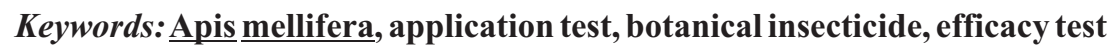

\begin{abstract}
ABSTRAK
Bioprotektor BP-1 merupakan insektisida nabati berbahan baku minyak cengkeh, serai wangi, dan temulawak. Hasil skrining dan uji toksisitas beberapa jenis minyak atsiri dan insektisida nabati menemukan bahwa insektisida Bioprotektor BP-1 yang berbahan aktif eugenol, sitronellal dan xanthorizol potensial untuk mengendalikan Varroa destructor pada lebah madu Apis mellifera. Penelitian dilakukan untuk mengetahui dosis efektif dan cara aplikasi insektisida nabati Bioprospektor BP-1 melalui uji aplikasi di laboratorium dan lapang. Hasil uji efikasi dalam 2 tahap dan uji aplikasi di laboratorium menunjukkan bahwa konsentrasi $10 \%$ dan dosis $0,25 \mathrm{ml}$ per liter volume sarang menghasilkan tingkat kematian $V$. destructor di atas $50 \%$ dengan efek kematian lebah yang rendah. Pengujian lebih lanjut di lapang menunjukkan bahwa konsentrasi 10\% dengan metode aplikasi semprot paling prospektif untuk mengendalikan tungau $V$. destructor pada koloni lebah madu A. mellifera.
\end{abstract}

Kata kunci: Apis mellifera, insektisida nabati, uji aplikasi, uji efikasi

\section{PENDAHULUAN}

Varroa destructor Anderson \& Trueman adalah tungau parasit lebah madu yang paling merugikan secara ekonomi pada budidaya Apis mellifera di seluruh dunia (Locke, 2012; Martin et al., 2012; Gonzáles-Cabrera et al., 2016), tidak terkecuali di Indonesia (Kuntadi \& Andadari, 2013). Upaya pengendalian hama secara kimiawi dalam jangka panjang terbukti menimbulkan efek resisten pada tungau tersebut (Adjlane et al., 2013; Asha \& Sharma, 2014; Goswami et al., 2014; Gonzáles-Cabrera et al., 2016; Kamler et al., 2016) dan residunya berisiko mencemari produk yang dihasilkan dari peternakan lebah madu (Çobanoğlu \& Tüze, 2008; Howis \& Nowakowski, 2009; Medici et al., 2012; Mahmood et al., 2014; Ostiguy \& Eitzer, 2014; Boi etal., 2016). 
Akarisida nabati merupakan salah satu bahan alternatif yang potensial digunakan untuk mengendalikan populasi tungau $V$. destructor. Selain ramah lingkungan, akarisida berbahan baku tumbuhan diharapkan tidak akan menimbulkan efek resisten pada organisme target (Mahmood et al., 2014). Beberapa jenis minyak atsiri, misalnya minyak cengkeh dan serai wangi, diketahui memiliki senyawa bioaktif yang dapat berfungsi sebagai pestisida (Asaad \& Wilis, 2012; Histo et al., 2014; Kumalasari, 2015). Beberapa diantaranya telah diramu menjadi produk pestisida nabati (Rizal, 2009).

Kuntadi dan Andadari (2013) telah menguji sepuluh jenis minyak atsiri atau insektisida nabati terhadap hama tungau $V$. destructor. Kesepuluh jenis minyak atsiri atau insektisida nabati tersebut yaitu minyak cengkeh (bahan aktif eugenol), minyak gandapura (bahan aktif methyl salisilat), minyak kayu putih (bahan aktif sineol), minyak kayu manis (bahan aktif sinamaldehida), minyak serai wangi (bahan aktif sitronellal), peppermint (bahan aktif menthol), cuka kayu (bahan aktif metanol dan asam asetat) dan tiga jenis insektisida nabati hasil produksi Balai Penelitian Perkebunan, yaitu campuran minyak cengkeh, minyak serai wangi dan minyak temulawak (bahan aktif eugenol, sitronellal dan xanthorizol), campuran minyak cengkeh dan minyak kayu manis (bahan aktif eugenol dan sinemaldehida) dan campuran minyak cengkeh dan minyak serai wangi (bahan aktif eugenol dan sitronellal). Hasil uji skrining dan uji toksisitas menunjukkan bahwa insektisida nabati yang diformulasikan dari campuran minyak cengkeh, serai wangi dan temulawak adalah bahan yang paling berpeluang digunakan sebagai akarisida dibanding minyak atsiri lainnya, karena kurang toksik terhadap lebah madu tetapi sangat toksik pada tungau $V$. destructor.

Sebagai tindak lanjut dari penelitian tersebut telah dilakukan penelitian untuk mendalami potensi insektisida nabati campuran minyak cengkeh, serai wangi dan temulawak sebagai akarisida dengan melakukan uji efikasi dan uji aplikasi. Penelitian bertujuan untuk mendapatkan informasi dosis dan metoda aplikasi yang paling efektif untuk mengendalikan tungau $V$. destructor pada koloni lebah madu A. mellifera.

\section{METODOLOGI}

\section{A. Lokasi Penelitian}

Penelitian dilakukan di peternakan lebah Desa Bantarjaya, Kecamatan Rancabungur, Kabupaten Bogor. Desa Bantarjaya termasuk salah satu tempat persinggahan sementara bagi beberapa peternak lebah dalam kegiatan penggembalaan lebah Apis mellifera, khususnya pada musim 'paceklik' nektar. Tanaman sumber pakan yang tersedia di Desa Bantarjaya didominasi tanaman jagung yang hanya menghasilkan serbuk sari. Kebutuhan nektar yang menjadi sumber karbohidrat lebah madu digantikan dengan air gula yang diberikan secara rutin. Dalam kondisi musim panceklik populasi koloni cenderung melemah dan serangan tungau $V$. destructor cenderung meningkat.

\section{B. Bahan dan Alat}

Bahan penelitian terdiri dari koloni lebah madu $A$. mellifera yang terserang $V$. destructor dan satu jenis insektisida nabati berbahan dasar minyak cengkeh, serai wangi dan temulawak. Insektisida nabati diperoleh dari Balai Penelitian Tanaman Obat dan Aromatika (Balittro) Bogor, dengan nama produksi Bioprotektor BP-1. Peralatan yang digunakan meliputi perlengkapan kerja perlebahan (pengasap, pakaian pelindung, pengungkit sarang, sikat lebah) dan perlengkapan aplikasi insektisida (sprayer, cawan petri).

\section{Prosedur Kerja}

Penelitian dilakukan dengan mengadakan uji efikasi dan uji aplikasi insektisida nabati. Uji Efikasi dimaksudkan untuk mendapatkan dosis efektif Bioprotektor BP-1 sebagai akarisida pengendali hama tungau $V$. destructor. Efektivitas akarisida diukur dari seberapa besar kemampuannya mengurangi atau menghilangkan tingkat infeksi tungau. Uji aplikasi dimaksudkan untuk mendapatkan cara aplikasi akarisida yang paling efektif.

\section{Pemilihan koloni}

Pemilihan koloni dilakukan melalui survei serangan tungau $V$. destructor di peternakan lebah A. mellifera guna mendapatkan koloni lebah dengan intensitas serangan yang relatif sama. Survei dilakukan dengan menghitung populasi tungau di lebah pekerja dewasa dan di sarang anakan lebah pada setiap koloni. 
Survei tingkat serangan $V$. destructor pada lebah dewasa dilakukan dengan mengambil sampel lebah pekerja dari dalam sarang (sedikitnya tidak kurang dari 100 ekor dari masing-masing koloni percobaan). Sampel lebah pekerja dimasukkan ke dalam botol gelas tembus pandang dan dimatikan dengan alkohol 70\%. Setelah semua lebah mati ditambahkan air bersih dan dikocok dengan kencang agar tungau yang menempel di badan lebah terlepas. Setelah itu, satu per satu lebah dikeluarkan dan dihitung jumlahnya. Setelah semua lebah dikeluarkan kemudian diamati dan dihitung jumlah tungau yang tertinggal. Persentase jumlah tungau terhadap jumlah sampel lebah pekerja dinilai sebagai persentase serangan pada masingmasing koloni yang diamati.

Survei tingkat serangaan $V$. destructor di sarang anakan dilakukan dengan membuka 100 sel pupa lebah pekerja dari sampel sarang yang diambil secara acak dari setiap koloni percobaan. Jumlah sel yang terserang tungau menunjukkan persentase serangan pada anakan lebah.

\section{Uji efikasi}

a. Uji in vitro

Uji efikasi secara in vitro di laboratorium dilakukan dalam 3 tahap, yaitu 2 tahap untuk mendapatkan konsentrasi insektisida nabati yang tepat dan 1 tahap berikutnya untuk mendapat-kan dosis efektif. Untuk mendapatkan tingkat konsentrasi yang dikehendaki, insektisida nabati dilarutkan dalam air.

Pada tahap 1 diuji 3 macam perlakuan konsentrasi insektisida nabati, masing-masing yaitu $100 \%, 50 \%$ dan $25 \%$, dibandingkan dengan kontrol yang tidak diberi perlakuan. Pada tahap 2 dilakukan uji coba 3 macam perlakuan konsentrasi, yaitu $20 \%$, $10 \%$ dan $5 \%$, dibanding-kan dengan kontrol yang tidak diberi perlakuan. Dosis yang digunakan dalam pengujian tersebut semua sama, yaitu $1 \mathrm{ml}$. Setelah diperoleh konsentrasi terkecil yang efektif selanjutnya dilakukan uji dosis. Pada uji dosis diuji tiga macam dosis insektisida nabati, yaitu $1 \mathrm{ml} ; 0,5 \mathrm{ml}$ dan $0,25 \mathrm{ml}$, dibandingkan dengan kontrol yang tidak diberi perlakuan.

Semua uji coba di atas dilakukan mengikuti Rancangan Acak Lengkap dengan ulangan masing-masing sebanyak 3 kali. Dalam percobaan secara in vitro di laboratorium digunakan cawan plastik sebagai tempat memelihara lebah dan tungau. Cawan berukuran satu liter dan diberi 3 lubang udara, yaitu 2 lubang masing-masing berukuran $2 \mathrm{~cm} \times 4 \mathrm{~cm}$ di dinding cawan dan satu lubang dengan ukuran $4 \mathrm{~cm} \times 4 \mathrm{~cm}$ di bagian tutup cawan. Semua lubang ventilasi ditutup dengan kain kasa halus untuk mencegah keluarnya lebah dan tungau.

Pada setiap percobaan setiap cawan plastik yang menjadi unit percobaan diisi 10 ekor lebah pekerja dewasa yang terserang tungau. Di atas kain kasa pada lobang udara yang berada ditutup cawan diberi kapas yang secara teratur diteteskan larutan gula untuk memberi makan lebah pekerja yang ada di dalamnya. Insektisida nabati diteteskan di kapas yang diletakkan di dasar cawan. Parameter yang diamati yaitu persen kematian lebah pekerja dan persen kematian tungau.

\section{b. Uji lapang}

Setelah diketahui konsentrasi dan dosis insektisida nabati yang efektif pada uji in vitro, selanjutnya konsentrasi dan dosis tersebut digunakan pada uji lapang. Khusus untuk dosis, volume penggunaan insektisida nabati digandakan menyesuaikan dengan volume kotak lebah berkisar 40 liter.

Uji lapang dilakukan berdasarkan Rancangan Acak Lengkap dengan ulangan sebanyak 3 kali. Unit percobaan adalah koloni lebah madu $A$. mellifera yang dipelihara menggunakan kotak type Langstroth berukuran volume 40 liter. Insektisida nabati diteteskan sesuai volume masing-masing perlakuan di gulungan kain kasa yang diletakkan di dasar kotak.

Parameter yang diamati adalah persentase serangan tungau pada lebah pekerja dewasa dan pupa serta persentase kematian anakan lebah. Persentase kematian anakan diamati untuk mengetahui sejauh mana pengaruh negatif penggunaan insektisida nabati. Sebelum dilakukan pemberian perlakuan dipilih secara acak $100 \mathrm{sel}$ sarang yang berisi telur. Sel tersebut digambar dalam sebuah plastik transparan yang diletakkan di salah satu permukaan sarang yang dipilih sebagai sampel dari setiap koloni percobaan. Pada hari ke-9, ke-100 sel sarang tersebut diamati perkembangannya dengan meletakkan plastik transparan yang telah bergambar tersebut di tempat yang sama seperti pada saat letak sel-sel tersebut digambar. Sel sarang yang masih terbuka dihitung sebagai kematian anakan, karena pada hari ke-9 setiap telur seharusnya sudah berkembang menjadi pupa yang tertutup selnya. Persen kematian anakan masing-masing koloni percobaan dihitung berdasarkan jumlah sampel sel yang tidak tertutup. 


\section{Uji aplikasi}

Uji aplikasi dimaksudkan untuk menguji cara pemakaian insektisida nabati yang paling mudah dan efektif untuk mengendalikan $V$. destructor, namun relatif aman bagi lebah madu. Pada uji aplikasi ini dilakukan percobaan tiga cara pemakaian insektisida nabati, yaitu:

a. Semprot. Insektisida nabati disemprotkan ke kerumunan lebah pekerja di kedua permukaan setiap sarang lebah di masing-masing koloni uji coba.

b. Strip. Potongan bilah tipis ukuran $12 \mathrm{~cm} \times 3$ $\mathrm{cm} \times 3 \mathrm{~mm}$ (panjang $\mathrm{x}$ lebar $\mathrm{x}$ tebal) yang sudah dicelupkan ke insektisida nabati diselipkan di antara bingkai-bingkai sarang.

c. Fumigasi. Insektisida nabati sebanyak $10 \mathrm{ml}$ diteteskan di kain kasa yang diletakkan di dasar kotak lebah.

Uji aplikasi menggunakan Rancangan Acak Lengkap dengan 3 perlakuan dan 3 ulangan. Konsentrasi insektisida nabati yang digunakan adalah $10 \%$. Parameter yang diamati dan metode pengambilan datanya sama dengan yang dilakukan pada uji lapang.

\section{Analisis Data}

Data dianalisis dengan sidik ragam menggunakan program statistik dengan perangkat lunak JMP dari SAS Institute. Apabila hasil analisis menunjukkan adanya perbedaan karena perlakuan, maka dilanjutkan dengan uji Tukey untuk mengetahui perbedaan antar perlakuan.

\section{HASIL DAN PEMBAHASAN}

\section{A. Hasil}

\section{Uji efikasi di laboratorium}

Uji efikasi secara in vitro dimaksudkan untuk menguji konsentrasi dan dosis larutan akarisida terhadap kematian lebah pekerja dewasa dan tungau. Hasil uji efikasi bioprotektor BP-1 tahap 1 pada berbagai konsentrasi di sajikan pada Tabel 1.

Tabel(Table) 1. Persentase kematian lebah pekerja dan tungau pada pemberian insektisida nabati BP-1 dengan konsentrasi $100 \%, 50 \%, 25 \%, 0 \%$ dengan dosis $1 \mathrm{ml}$ (Mortality percentages of worker honey bees and mites after treated with 100\%, 50\%, 25\%, 0\% in concentrations of botanical insecticide Bioprotektor BP-1 at $1 \mathrm{ml}$ dose)

\begin{tabular}{llcccc}
\hline \multirow{2}{*}{$\begin{array}{c}\text { Waktu dan subyek pengamatan } \\
\text { (Time and subject of observations) }\end{array}$} & \multicolumn{4}{c}{ Mortalitas (Mortality) (\%) } \\
\cline { 2 - 5 } Jam ke-1 & Lebah pekerja & $0 \pm 0 \mathrm{c}$ & $32 \pm 16 \mathrm{~b}$ & $43 \pm 11 \mathrm{~b}$ & $80 \pm 10 \mathrm{a}$ \\
$\left(1^{\text {st }}\right.$ hour $)$ & (Worker bees) & & $25 \%$ & $50 \%$ & $100 \%$ \\
& Tungau (Mites) & $10 \pm 10 \mathrm{~b}$ & $77 \pm 21 \mathrm{a}$ & $83 \pm 12 \mathrm{a}$ & $100 \pm 0 \mathrm{a}$ \\
Jam ke-2 & Lebah pekerja & $0 \pm 0 \mathrm{~d}$ & $58 \pm 9 \mathrm{c}$ & $76 \pm 5 \mathrm{~b}$ & $98 \pm 2 \mathrm{a}$ \\
$\left(2^{\text {nd }}\right.$ hour $)$ & (Worker bees) & $10 \pm 10 \mathrm{~b}$ & $97 \pm 6 \mathrm{a}$ & $90 \pm 17 \mathrm{a}$ & $100 \pm 0 \mathrm{a}$ \\
\hline
\end{tabular}

Keterangan (Remarks): Nilai rata-rata diikuti huruf yang sama pada baris yang sama tidak berbeda nyata pada taraf $5 \%$ (The mean values followed by the same letter at the same row are not significantly different at $5 \%$ )

Hasil analisis data menunjukkan adanya pengaruh perlakuan yang sangat nyata $(\mathrm{P}<0,01)$ terhadap tingkat kematian lebah maupun tungau. Pada satu jam pertama tingkat kematian tungau di atas $50 \%$ untuk ketiga konsentrasi insektisida nabati, dimana tidak ada perbedaan antara ratarata tingkat kematian tungau pada perlakuan konsentrasi 25\%, 50\%, dan 100\%. Meskipun tingkat kematian lebah lebih rendah dibanding kematian tungau, namun seiring berjalannya waktu, tingkat kematian lebah semakin meningkat sebagaimana juga terjadi pada tungau. Hal ini terlihat pada pengamatan jam ke 2, dimana pada perlakuan dengan konsentrasi terkecil (25\%) tingkat kematian lebah sudah di atas 50\%. Hasil percobaan tahap awal ini menunjukkan bahwa konsentrasi insektisida nabati yang digunakan masih terlalu toksik bagi spesies bukan target.

Hasil uji efikasi tahap 2 dengan konsentrasi insektisida nabati yang lebih kecil (konsentrasi $20 \%, 10 \%, 5 \%$ dan $0 \%$ ) dapat dilihat pada Tabel 2.

Hasil analisis data menunjukkan bahwa konsentrasi 10\% menghasilkan tingkat kematian yang masih cukup tinggi pada tungau, namun relatif rendah pada lebah pekerja dewasa. Oleh karena itu, konsentrasi 10\% digunakan sebagai tolok ukur untuk pengujian lebih lanjut, yaitu uji dosis efektif insektisida nabati. 
Tabel (Table) 2. Persentase kematian lebah pekerja dan hama tungau pada pemberian insektisida nabati Bioprotektor BP-1 dengan konsentrasi 20\%, 10\%, 5\%, 0\%, dosis $1 \mathrm{ml}$ (Mortality percentages of worker honey bees and mites after being treated with $20 \%, 10 \%, 5 \%, 0 \%$ in concentrations of botanical insecticide Bioprotektor BP-1 at $1 \mathrm{ml}$ dose)

\begin{tabular}{|c|c|c|c|c|c|}
\hline \multirow{2}{*}{\multicolumn{2}{|c|}{$\begin{array}{l}\text { Waktu dan subyek pengamatan } \\
\text { (Time and subject of observations) }\end{array}$}} & \multicolumn{4}{|c|}{ Mortalitas (Mortality) (\%) } \\
\hline & & $0 \%$ & $5 \%$ & $10 \%$ & $20 \%$ \\
\hline \multirow[t]{2}{*}{$\begin{array}{l}\text { Jam ke-1 } \\
\left(1^{\text {st }} \text { hour }\right)\end{array}$} & $\begin{array}{l}\text { Lebah pekerja } \\
\text { (Worker bees) }\end{array}$ & $0 \pm 0 \mathrm{a}$ & $0 \pm 0 \mathrm{a}$ & $3 \pm 5 a$ & $26 \pm 25 a$ \\
\hline & Tungau (Mites) & $0 \pm 0 \mathrm{~b}$ & $3 \pm 6 b$ & $40 \pm 10 a$ & $40 \pm 20 a$ \\
\hline \multirow[t]{2}{*}{$\begin{array}{l}\text { Jam ke-2 } \\
\left(2^{\text {nd }} \text { hour }\right)\end{array}$} & $\begin{array}{l}\text { Lebah pekerja } \\
\text { (Worker bees) }\end{array}$ & $0 \pm 0 \mathrm{a}$ & $1 \pm 2 \mathrm{a}$ & $26 \pm 11 \mathrm{a}$ & $36 \pm 35 \mathrm{a}$ \\
\hline & Tungau (Mites) & $0 \pm 0 \mathrm{~b}$ & $10 \pm 10 b$ & $67 \pm 25 \mathrm{a}$ & $63 \pm 21 a$ \\
\hline \multirow[t]{2}{*}{$\begin{array}{l}\text { Jam ke-3 } \\
\left(3^{\text {rd hour })}\right.\end{array}$} & $\begin{array}{l}\text { Lebah pekerja } \\
\text { (Worker bees) }\end{array}$ & $0 \pm 0 \mathrm{~b}$ & $1 \pm 2 b$ & $40 \pm 17 \mathrm{a}$ & $47 \pm 32 \mathrm{a}$ \\
\hline & Tungau (Mites) & $0 \pm 0 \mathrm{~b}$ & $13 \pm 6 b$ & $77 \pm 32 \mathrm{a}$ & $70 \pm 30 a$ \\
\hline
\end{tabular}

Keterangan(Remarks): Nilai rata-rata diikuti huruf yang sama pada baris yang sama tidak berbeda nyata pada taraf $5 \%$ (The mean values followed by the same letter at the same row are not significantly different at $5 \%$ )

Uji dosis dimaksudkan untuk mengetahui dosis terkecil pada tingkat konsentrasi larutan insektisida nabati yang juga terkecil tetapi masih cukup efektif untuk mengendalikan tungau. Dosis yang digunakan selama uji efikasi tahap 1 dan 2, yakni sebanyak $1 \mathrm{ml}$, dipakai sebagai dosis tertinggi pada uji dosis yang dilakukan. Pada uji dosis digunakan empat perlakuan, terdiri dari 1 $\mathrm{ml} ; 0,5 \mathrm{ml} ; 0,25 \mathrm{ml}$ dan $0 \mathrm{ml}$ (kontrol). Data pengamatan persentase kematian lebah pekerja dan tungau setelah pemberian perlakuan tertera pada Tabel 3.

Hasil analisis data menunjukkan dosis $0,25 \mathrm{ml}$ paling berpeluang sebagai tolok ukur untuk digunakan dalam pengendalian tungau $V$. destructor mengunakan insektisida nabati Bioprotektor BP-1. Hal ini ditunjukkan oleh tingkat kematian yang tinggi pada tungau, namun sangat rendah efeknya terhadap lebah pekerja dewasa sebagai ditunjukkan nilai rataan mortalitas kedua parameter yang diamati pada jam ke-18.

\section{Uji efikasi di lapangan}

Dengan hasil di atas maka uji lapang tahap 1 dilakukan untuk menguji dosis tersebut $(0,25 \mathrm{ml}$ per 1) sebagai tolok ukur dosis tertinggi setelah disesuaikan dengan ukuran kotak lebah yang volumenya sekitar 40 liter. Pada percobaan lapangan tahap 1 diuji 3 macam dosis, yaitu 7,5 $\mathrm{ml}, 5 \mathrm{ml}$ dan $2,5 \mathrm{ml}$, dengan konsentrasi $10 \%$. Penggunaan dosis 7,5 $\mathrm{ml}$ sebagai dosis tertinggi dihitung berdasarkan hasil perkalian dosis efektif hasil uji laboratorium $(0,25 \mathrm{ml})$ dengan volume kotak lebah setelah dikurangi perkiraan volume sarang dan lebah.

Tabel (Table) 3. Persentase kematian lebah pekerja dan tungau pada pemberian insektisida nabati BP-1 dengan dosis $1 \mathrm{ml}, 0,5 \mathrm{ml}, 0,25 \mathrm{ml}$ dan $0 \mathrm{ml}$, konsentrasi 10\% (Mortality percentages of worker honey bees and mites after treated with $1 \mathrm{ml}, 0,5 \mathrm{ml}, 0,25 \mathrm{ml}$ and $0 \mathrm{ml}$ in doses of botanical insecticide Bioprotektor BP-1 at 10\% concentration)

\begin{tabular}{llcccc}
\hline \multirow{2}{*}{$\begin{array}{c}\text { Waktu dan subyek pengamatan } \\
\text { (Time and subject of observations) }\end{array}$} & \multicolumn{4}{c}{ Mortalitas (Mortality) (\%) } \\
\cline { 2 - 5 } Jam ke-1 & $\begin{array}{l}\text { Lebah pekerja } \\
\left(1^{\text {St }} \text { hour }\right)\end{array}$ & $2 \pm 3 \mathrm{~m}$ & $0,25 \mathrm{ml}$ & $0,5 \mathrm{ml}$ & $1,0 \mathrm{ml}$ \\
& $\begin{array}{l}\text { (Worker bees) } \\
\text { Tungau (Mites) }\end{array}$ & $0 \pm 0 \mathrm{a}$ & $3 \pm 3 \mathrm{a}$ & $10 \pm 9 \mathrm{a}$ \\
$\left(2^{\text {nd }}\right.$ hour $)$ & $\begin{array}{l}\text { Lebah pekerja } \\
\text { (Worker bees) }\end{array}$ & $3 \pm 3 \mathrm{a}$ & $7 \pm 12 \mathrm{~b}$ & $50 \pm 26 \mathrm{a}$ & $87 \pm 5 \mathrm{a}$ \\
Jam ke-18 & $\begin{array}{l}\text { Tungau (Mites) } \\
\left(18^{\text {th }} \text { hour }\right)\end{array}$ & $0 \pm 0 \mathrm{c}$ & $10 \pm 0 \mathrm{c}$ & $53 \pm 23 \mathrm{~b}$ & $93 \pm 6 \mathrm{a}$ \\
& $\begin{array}{l}\text { Lebah pekerja } \\
\text { (Worker bees) }\end{array}$ & $5 \pm 5 \mathrm{~b}$ & $9 \pm 13 \mathrm{~b}$ & $60 \pm 5 \mathrm{a}$ & $59 \pm 13 \mathrm{a}$ \\
& Tungau (Mites) & $10 \pm 10 \mathrm{~b}$ & $80 \pm 0 \mathrm{a}$ & $77 \pm 21 \mathrm{a}$ & $97 \pm 6 \mathrm{a}$ \\
\hline
\end{tabular}

Keterangan (Remarks): Nilai rata-rata diikuti huruf yang sama pada baris yang sama tidak berbeda nyata pada taraf $5 \%$ (The mean values followed by the same letter at the same row are not significantly different at $5 \%$ ) 
Hasil uji efikasi insektisida nabati di lapangan tahap 1 menunjukkan tidak adanya penurunan populasi tungau setelah pemberian perlakuan, bahkan ada kecenderungan peningkatan populasi baik yang ada di lebah dewasa maupun di dalam sarang anakan (Gambar 1 dan 2). Tampaknya dosis yang digunakan tidak efektif untuk menurunkan populasi tungau. Hasil ini jauh berbeda dengan hasil uji laboratorium, dimana pemberian perlakuan menghasilkan efek yang berbeda terhadap kontrol.

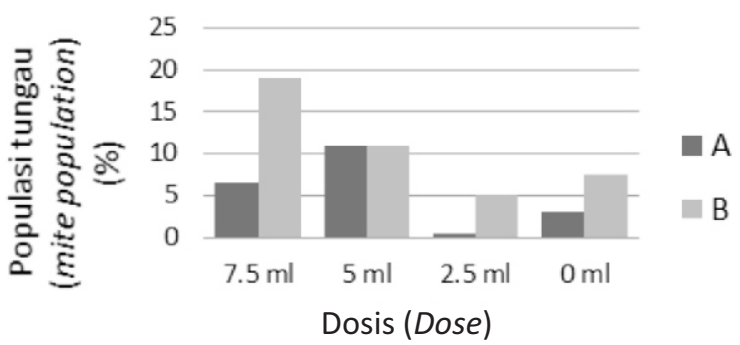

Gambar(Figure) 1. Populasi tungau pada lebah pekerja sebelum (A) dan sesudah (B) perlakuan dosis insektisida nabati dengan konsentrasi $10 \%$ (Population of phoretic mites before (A) and after (B) treatment with 4 doses of botanical insecticide at $10 \%$ concentration)

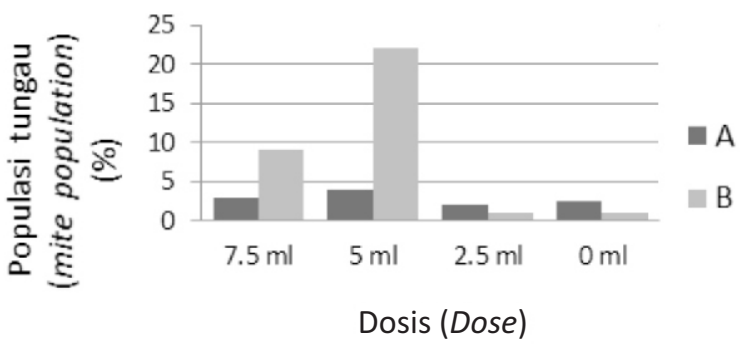

Gambar(Figure) 2. Populasi tungau pada sel sarang sebelum (A) dan sesudah (B) perlakuan dosis insektisida nabati dengan konsentrasi 10\% (Mite population in worker brood before (A) and after (B) treatment with 4 doses of botanical insecticide at $10 \%$ concentration)

Mengingat pada saat uji efikasi insektisida nabati di laboratorium data pengamatannya menunjukkan tidak ada perbedaan antara konsentrasi 10\% dengan konsentrasi 20\% (Tabel 2), maka uji lapang dilanjutkan ke tahap 2 dengan meningkatkan konsentrasi insektisida nabati yang digunakan. Uji lapang tahap 2 dilakukan dengan dosis yang sama dengan tahap 1, namun konsentrasinya ditingkatkan menjadi $20 \%$. Hasil pengujian sebagaimana terlihat pada Gambar 3 dan 4. Hasil uji coba menunjukkan penurunan populasi tungau pada penggunaan dosis $7,5 \mathrm{ml}$ dan $5 \mathrm{ml}$, baik tungau yang ada di lebah pekerja dewasa maupun yang ada di dalam sel sarang anakan lebah. Sementara untuk dosis 2,5 $\mathrm{ml}$ dan kontrol yang tidak diberi perlakuan justru terjadi peningkatan populasi tungau.

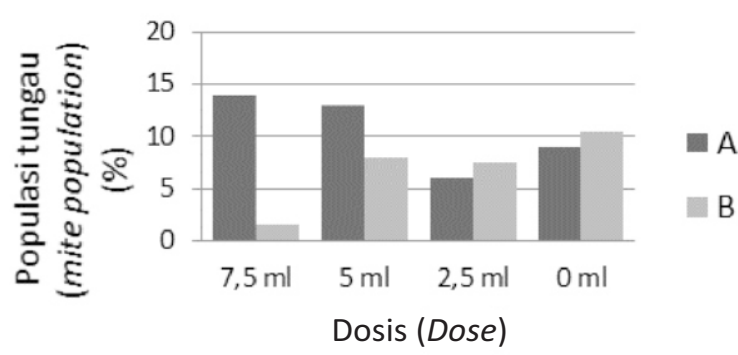

Gambar(Figure)3. Populasi tungau pada lebah pekerja sebelum (A) dan sesudah (B) perlakuan dosis insektisida nabati dengan konsentrasi $20 \%$ (Population of phoretic mites before (A) and after (B) treatment with 4 doses of botanical insecticide at $20 \%$ concentration)

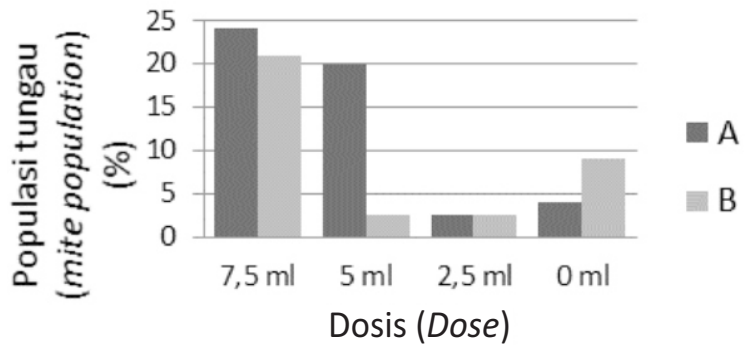

Gambar(Figure) 4. Populasi tungau pada sel sarang sebelum (A) dan sesudah (B) perlakuan dosis insektisida nabati dengan konsentrasi 20\% (Mite population in worker brood before (A) and after (B) treatment with 4 doses of botanical insecticide at $20 \%$ concentration)

Apabila dibandingkan dengan hasil uji coba tahap 1 yang menggunakan konsentrasi $10 \%$, maka konsentrasi 20\% memperlihatkan hasil yang lebih prospektif. Namun apabila keduanya dibandingkan menurut tingkat kematian anakan yang dapat ditimbulkannya, maka konsentrasi $20 \%$ jauh lebih berbahaya pada anakan lebah 
(Gambar 5 dan 6). Tingkat kematian anakan pada perlakuan dengan konsentrasi $10 \%$ rata-rata hanya sekitar $20 \%$, sedikit di atas tingkat kematian anakan dari koloni kontrol yang tidak diberi perlakuan (rata-rata sekitar 13\%). Sementara pada perlakuan dengan konsentrasi $20 \%$ tingkat kematian anakan lebah sekitar $50 \%$, bahkan untuk dosis $7,5 \mathrm{ml}$ di atas $60 \%$. Dengan tingkat kematian yang sangat tinggi, maka penggunaan insektisida nabati Bioprotektor BP1 dengan konsentrasi 20\% akan menghambat perkembangan populasi lebah.

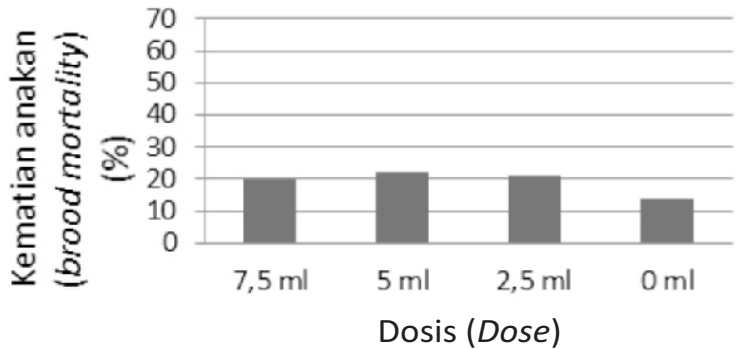

Gambar(Figure)5. Kematian anakan lebah pada perlakuan dosis insektisida nabati dengan konsentrasi 10\% (Brood mortality after treated with 4 doses of botanical insecticide at $10 \%$ concentration)

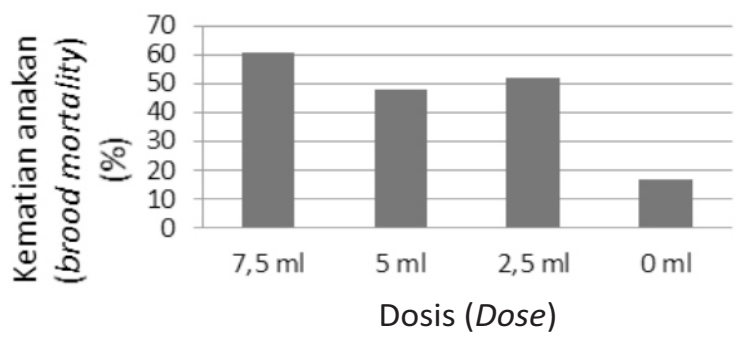

Gambar(Figure)6. Kematian anakan lebah pada perlakuan dosis insektisida nabati dengan konsentrasi 20\% (Brood mortality after treated with 4 doses of botanical insecticide at $20 \%$ concentration)

\section{Uji aplikasi}

Berdasarkan pertimbangan bahwa konsentrasi insektisida nabati Bioprotektor sebesar 20\% beresiko pada kematian anakan lebah yang cukup tinggi, maka uji aplikasi tetap menggunakan konsentrasi 10\% karena ada kemungkinan bahwa tidak bekerjanya insektisida nabati pada tahap uji lapangan berhubungan dengan metode aplikasi yang digunakan. Pemberian insektisida nabati di dasar kotak dengan konsentrasi yang kecil diduga menyebabkan tidak bekerjanya fungsi akarisida secara baik. Sebagaimana diketahui, zat aktif insektisida bekerja melalui beberapa cara antara lain kontak, penguapan, repelen dan lain-lain (Arshad et al., 2014; Zoubiri \& Baaliouamer, 2014). Oleh karena itu, penggunaan konsentrasi $10 \%$ masih berpeluang dapat bekerja secara efektif apabila diaplikasikan secara tepat.

Hasil uji aplikasi menggunakan cara semprot, strip dan fumigasi di dasar kotak menunjukkan bahwa konsentrasi 10\% dengan metode aplikasi semprot cukup efektif menurunkan populasi tungau, baik yang ada di lebah pekerja dewasa maupun sel sarang anakan (Gambar 7 dan Gambar 8). Sementara aplikasi menggunakan strip terlihat cukup efektif menurunkan populasi tungau di sel sarang, tetapi tidak terlihat cukup baik untuk tungau yang ada di lebah dewasa. Hal ini kemungkinan disebabkan dosis insektisida di strip relatif kecil, yaitu sekitar $1 \mathrm{ml}$ untuk setiap strip. Dengan demikian penggunaan strip dalam jumlah yang lebih banyak ada kemungkinan akan memberikan hasil yang lebih baik untuk pengendalian hama $V$. destructor.

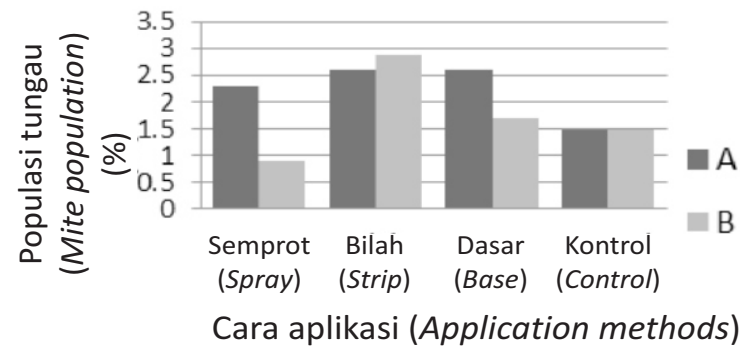

Gambar(Figure) 7. Populasi tungau di lebah pekerja sebelum (A) dan sesudah (B) perlakuan cara aplikasi insektisida nabati (Population of phoretic mites before (A) and after (B) treatment with 4 different methods of pesticide application)

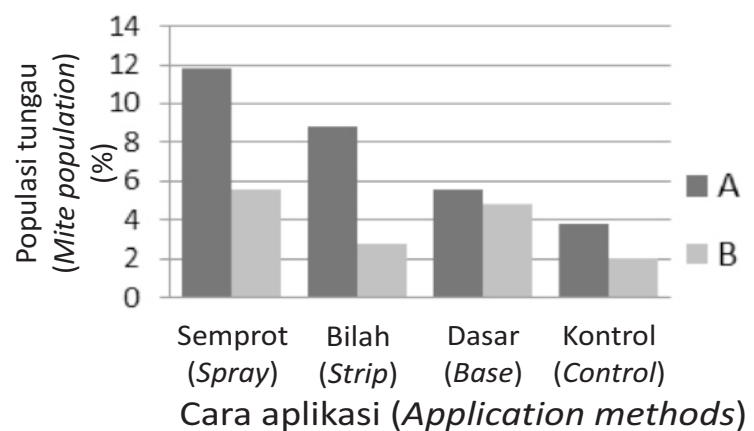

Gambar(Figure) 8. Populasi tungau di sel sarang anakan lebah sebelum dan sesudah (B) perlakuan cara aplikasi insektisida nabati (Mite population in worker brood cells before and after treatment with 4 different methods of pesticide application) 
Hasil uji aplikasi di atas, tampaknya metode semprot dapat digunakan untuk aplikasi insektisida nabati Bioprotektor BP-1 pada koloni lebah madu. Selain mampu menurunkan populasi tungau yang ada di dalam sel sarang dan yang menempel di lebah pekerja, metode aplikasi ini juga relatif aman bagi anakan lebah. Gambar 9 dapat dilihat bahwa tingkat kematian anakan lebah madu relatif rendah pada metode aplikasi semprot.

\section{B. Pembahasan}

Hama tungau $V$. destructor masih menjadi persoalan penting di dalam budidaya lebah madu A. mellifera. Serangan hama ini dan infeksi virus yang menyertainya diduga kuat ikut andil terjadinya peristiwa colony collapse disorder (CCD) di berbagai belahan dunia yang telah mengakibatkan musnahnya sebagian besar koloni A. mellifera yang dibudidayakan (Gonzáles-Cabrera et al., 2016). Mengutip data Kementerian Kehutanan tahun 1997, Kuntadi \& Andadari (2013) mengatakan bahwa Indonesia pernah mengalami kehilangan sekitar $50-60 \%$ populasi koloni $A$. mellifera pada pertengahan tahun 1990-an akibat ledakan hama $V$. destructor. Meskipun outbreak sejenis tidak terjadi lagi, namun seranggan hama tungau terus terjadi di peternakan lebah dan tetap menjadi ancaman serius bagi kegiatan budidaya $A$. mellifera di
Indonesia (Widyasari, 2006; Budiwijono, 2012; Widiarti \& Kuntadi, 2012; Kuntadi \& Andadari, 2013).

Peternak A. mellifera pada umumnya melakukan pengobatan secara rutin sebagai upaya untuk meminimalisir dampak kerusakan koloni lebah akibat hama tungau. Jenis pestisida yang digunakan antara lain Apistan ${ }^{\mathrm{TM}}$ dan Mavrik ${ }^{\mathrm{TM}}$ dengan bahan aktif masing-masing yakni fluvalinate dan amitraz (Kuntadi \& Andadari, 2013). Beberapa tahun terakhir digunakan Rotraz 200 EC (Budiwijono, 2012) setelah kedua obat pestisida terdahulu tidak tersedia lagi di pasaran. Rotraz 200 EC adalah insektisida atau akarasida kontak dengan bahan aktif amitraz yang biasa digunakan di pertanian untuk membasmi kutu dan hama serangga. Teknik pengobatan lainnya yakni menggunakan campuran kapur barus (kamper) dan belerang (sulfur). Tampaknya pengobatan yang dilakukan peternak cukup efektif menekan perkembangan hama (Widiarti \& Kuntadi, 2012), meskipun rutinitas pengobatan diakui banyak peternak (komunikasi pribadi) mulai menampakkan munculnya gejala resistensi. Secara empirik, gejala resistensi $V$. destructor pada bahan kimia tertentu seperti amitraz dan lain-lain sudah terdeteksi di berbagai hasil penelitian (Maggi et al., 2009; Maggi et al., 2010). Oleh sebab itu diperlukan bahan-bahan baru yang, di satu sisi, dapat secara efektif mengontrol perkembangan hama dan di sisi lain, relatif tidak meninggalkan

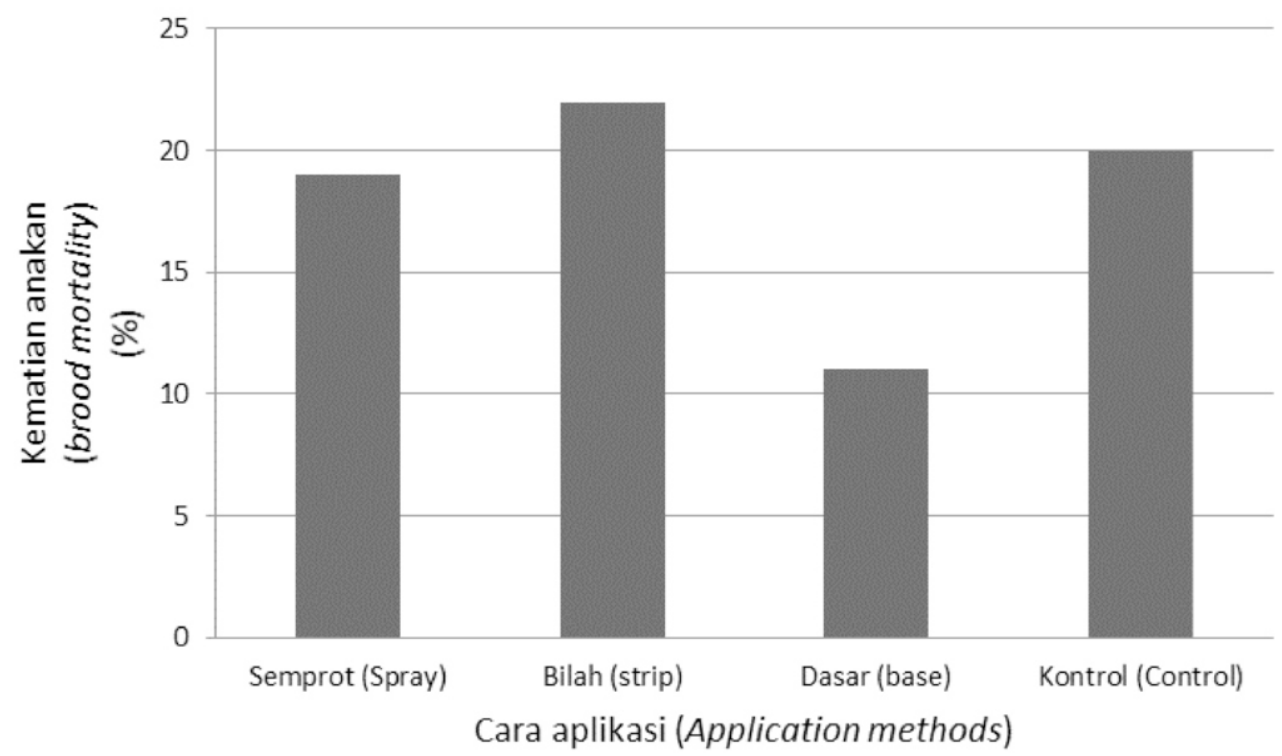

Gambar(Figure) 9. Tingkat kematian anakan lebah setelah perlakuan insektisida nabati BP-1 konsentrasi 10\% dengan 4 metode aplikasi (Brood mortality of honey bees after treated with $10 \%$ concentration of bio-insecticide BP-1 in 4 different methods of application) 
residu yang dapat mencemari produk-produk perlebahan. Minyak atsiri termasuk bahan yang layak dipertimbangkan mengingat banyak di antaranya dapat berfungsi sebagai pestisida (ElZemitry et al., 2006). Minyak atsiri bersifat volatile dan mudah terdegradasi dengan toksisitas rendah sehingga zat aktif di dalamnya diharapkan tidak menjadi bahan pencemar yang membahayakan (Hartati, 2012; Arshad et al., 2014).

Berbagai jenis minyak atsiri dan insektisida nabati telah diuji coba untuk mengendalikan hama V. destructor (Qayyoum et al., 2013; Goswami et al., 2014; Mahmood et al., 2014; Ruffinengo et al., 2014; Azis et al., 2015), banyak diantaranya memperlihatkan prospek yang baik. Kuntadi dan Andadari (2013) telah menguji beberapa jenis minyak atsiri dan insektisida nabati dan menyatakan bahwa insektisida nabati yang disintesis dari minyak cengkeh, serai wangi dan temulawak merupakan bahan yang paling prospektif digunaan untuk mengendalikan tungau $V$. destructor. Insektisida nabati yang sama digunakan dalam penelitian ini untuk mencari dosis dan konsentrasi yang tepat serta cara aplikasi yang sesuai.

Insektisida nabati Bioprotektor BP-1 mengandung zat aktif eugeno, sitronellal dan xanthorizol yang berasal dari minyak cengkeh, serai wangi dan temulawak (Rizal, 2009). Bioprotektor BP-1 antara lain berfungsi sebagai insektisida (obat anti serangga) dan akarisida (obat anti tungau) dengan organisme pengganggu tanaman (OPT) sasaran antara lain thrips, kutu, tungau. Hasil uji efikasi secara in vitro menunjukkan bahwa pada konsentrasi di atas $25 \%$ BP-1 memiliki daya racun yang tinggi pada organisme target ( $V$. destructor) maupun non target (lebah pekerja A. mellifera) (Tabel 1). Kekuatan fungsi BP-1 sebagai pestisida juga terlihat pada Tabel 3 dimana kematian organisme target dan non target masih cukup tinggi pada saat dosis yang diberikan di atas $0,25 \mathrm{ml}$ per 1 dengan konsentrasi relatif rendah $(<20 \%)$, walaupun membutuhkan waktu yang lebih lama. Uji coba pada hama lain juga memperlihatkan bahwa aplikasi Bioprotektor BP-1 mampu menekan tingkat serangan hama, antara lain penggerek batang Helopeltis antonii dan Conopomorpha cramerella pada tanaman kakao (Willis et al., 2010; Asaad \& Willis, 2012) dan hama Crocidolomia binotalis pada tanaman brokoli (Willis et al., 2013).

Kemampuan BP-1 menekan serangan hama tampaknya sangat ditentukan oleh kandungan zat aktif eugenol dan sitronellal dari minyak cengkeh dan serai wangi yang menjadi bahan utamanya. Beberapa penelitian sebelumnya membuktikan bahwa ke dua zat aktif tersebut mempunya daya bunuh dan daya tolak terhadap beberapa jenis organisme pengganggu tanaman seperti serangga, nematoda, fungi, tungau (Wiratno, 2008; Balfas \& Willis, 2009; Djiwanti \& Wiratno, 2011; Wiratno, 2011; Kuntadi \& Andadari, 2013). Komponen lainnya di dalam insektisida nabati BP-1 yakni xanthorizol yang berasal dari ektrak rimpang temulawak dikenal memiliki sifat antimikroba (Rukayadi et al., 2006; Handayani et al., 2007; Djiwanti \& Wiratno, 2011; Sundararajan et al., 2014).

Meskipun dalam uji in vitro menunjukkan hasil positif, namun aplikasi BP-1 membutuhkan konsentrasi larutan yang lebih tinggi daripada dosis anjuran (5 $\mathrm{ml}$ per 1 air). Pada uji aplikasi BP-1 secara in vitro diperlukan konsentrasi di atas $10 \%$ dengan dosis $1 \mathrm{ml}$ untuk dapat menghasilkan kematian tungau $V$. destructor di atas 50\% (Tabel 2). Pada uji lapang, hasil positif BP-1 sebagai akarisida juga baru terlihat pada saat konsentrasi yang digunakan sebesar 20\% (Gambar 3 dan Gambar 4), namun dengan resiko kematian yang tinggi pada lebah (Gambar 5 dan Gambar 6). Hal ini tampaknya disebabkan karena pada uji efikasi di laboratorium maupun di lapang BP-1 diaplikasikan sebagai insektisida fumigant, sementara dosis anjuran $5 \mathrm{ml}$ per 1 air atau setara dengan konsentrasi larutan 0,5\% yakni untuk penggunaan melalui cara semprot sebagai racun kontak atau sistemik. Hasil uji aplikasi membuktikan hal tersebut, dimana aplikasi BP-1 sebagai racun kontak dengan metoda semprot lebih tinggi daya racunnya daripada diaplikasikan sebagai fumigant baik dengan cara strip yang diletakkan diantara bingkai sarang maupun yang diletakkan di dasar kotak sarang (Gambar 7 dan Gambar 8). Tampaknya bioaktifitas eugenol, sitronellal dan xantorhizol yang termasuk memiliki sifat sebagai racun sistemik atau kontak untuk hama tertentu (Deletre et al., 2013; Kumalasari, 2015) menjadikan metoda semprot lebih efektif untuk aplikasi insektisida Bio-protektor BP-1 .

Meskipun hasil penelitian ini memberikan gambaran positif terhadap potensi Bioprotektor BP-1 untuk mengendalikan tungau $V$. destructor pada koloni lebah madu $A$. mellifera, namun sedikitnya ada 2 tantangan yang perlu dicari-kan jalan keluar dalam penggunaan pestisida nabati. Pertama, bahan baku dan kandungan pestisida nabati umumnya merupakan senyawa volatile dan mudah terdegradasi di alam (Hartati, 2012; 
Arshad et al., 2014) dan cenderung tidak stabil serta tidak bertahan lama pada sarang lebah yang bersifat lipofilik (Girisgin et al., 2014), sehingga daya bunuh atau daya tolak yang dimiliki menjadi sangat terbatas dengan jangka waktu yang relatif pendek. Sebagai contoh, eugenol dari minyak cengkeh hanya bertahan antara 2-3 minggu di lilin sarang lebah (Girisgin et al., 2014). Dengan demikian efektivitasnya menjadi berkurang mengingat keberadaan tungau $V$. destructor di dalam koloni lebah tidak hanya menempel (foretik) di lebah dewasa, tetapi juga bereproduksi di dalam sel pupa yang tertutup. Menurut Medici et al. (2015), agar suatu akarisida efektif digunakan untuk mengendalikan $V$. desructor di dalam koloni lebah maka akarisida tersebut harus dapat bertahan selama 45 hari di dalam stup (hive).

Persoalan kedua berkaitan dengan penggunaan insekisida nabati pada lebah madu adalah potensi cemaran pada produk perlebahan. Penggunaan metoda semprot membawa konsekuensi yang lebih besar kepada potensi cemaran pada produk lebah madu mengingat aplikasinya secara langsung mengena sarang lebah di mana terdapat madu dan serbuk sari yang merupakan bahan pangan. Meskipun insektisida nabati tergolong ramah lingkungan dan memiliki daya racun rendah pada manusia dan mamalia (Girisgin et al., 2014), namun pada umumnya memiliki aroma dan rasa yang kuat, sehingga residu yang ditinggalkan sekurangnya dapat mengganggu keaslian rasa dan aroma madu. Mengingat hal tersebut, pemanfaatan BP-1 sebagai akarisida untuk pengendalian tungau $V$. destructor masih memerlukan kajian lebih dalam khususnya berkaitan dengan waktu dan cara aplikasi supaya di satu sisi penggunaannya lebih efektif dan di sisi lain potensi cemarannya dapat diminimalisir.

\section{KESIMPULAN DAN SARAN}

\section{A. Kesimpulan}

Uji efikasi insektisida nabati Bioprotektor BP-1 dengan bahan aktif eugenol, sitronellal dan xanthorizol dan uji dosis secara in vitro di laboratorium menunjukkan bahwa konsentrasi $10 \%$ dan dosis $0,25 \mathrm{ml}$ per liter volume sarang menghasilkan tingkat kematian $V$. destructor di atas $50 \%$ dengan efek kematian individu lebah pekerja yang rendah. Pengujian lapang menunjukkan bahwa konsentrasi 10\% dengan metode aplikasi semprot paling efektif untuk mengurangi populasi tungau $V$. destructor pada koloni lebah madu $A$. mellifera daripada 2 metode aplikasi lainnya yakni fumigasi dan strip dengan resiko kematian anakan lebah yang relatif kecil.

Hasil tersebut di atas memperlihatkan bahwa metode aplikasi sangat menentukan efektifitas dari penggunaan insektisida nabati pada tingkat konsentrasi dan dosis yang sama. Pada insektisida nabati Bioprotektor BP-1 yang diformulasikan dari minyak cengkeh, serai wangi dan rimpang temulawak, penerapannya sebagai racun kontak melalui aplikasi semprot langsung pada sarang dan lebah memperlihatkan hasil yang cukup prospektif untuk digunakan sebagai obat pengendali tungau parasit $V$. destructor pada koloni lebah madu $A$. mellifera.

\section{B. Saran}

Perlu kajian lebih mendalam berkaitan dengan metode aplikasi Bioprotektor BP-1 agar bioaktivitasnya memiliki waktu efektif yang lebih lama, sehingga dapat dihindari aplikasi berlebihan secara berulang-ulang untuk memperoleh hasil yang optimal. Penggunaan mikrokapsul dapat dipertimbangkan untuk dikaji sebagai alternatif metode aplikasi Bioprotektor BP-1 untuk pengendalian tungau $V$. destructor pada koloni lebah madu A. mellifera.

\section{UCAPAN TERIMAKASIH}

Penulis menyampaikan ucapan terima kasih kepada jajaran menejemen Pusat Penelitian dan Pengembangan Hutan yang telah memfasilitasi pelaksanaan penelitian ini. Ucapan terima kasih juga Penulis sampaikan kepada teknisi dan petugas pengelola ternak lebah sdr. Suminta yang telah membantu dalam pengum-pulan data di lapang.

\section{DAFTAR PUSTAKA}

Adjlane, N., Doumandji, S.E., \& Haddad, N. (2013). Varroa destructor resistance to fluvalinate in Algeria. Trends Entomol, 12, 123-125.

Arshad, Z., Hanif, M.A., Qadri, R.W.K., \& Khan, M.M. (2014). Role of essential oils in plant diseases protection: A review. International $J$. of Chem. And Biochem. Sci., 6, 11-17.

Asaad, M., \& Wilis, M. (2012). Kajian pestisida nabati yang efektif terhadap hama penggerek buah 
kakao (PBK) pada tanaman kakao di Sulawesi Selatan. Suara Perlindungan Tanaman, 2(2), 24-34.

Asha, R.G., \& Sharma, S.K. (2014). Comparative evaluation of oxalic acid and formic acid against Varroa destructor Andeson and trueman in Apis meillifera L. colonies. $J$. Entomology and Zoology Studies, 2(4), 119124.

Azis, M.A., Azeem, M., Ahmed, M.S., Siddique, F., \& Jamal, M. (2015). Control of Varroa destructor Anderson and Trueman (Acari: Varroidae) on Apis mellifera linguistica by using thymol and formic acid in Pothwar region of Punjab, Pakistan. Asian J. Agri Biol., 3(4), 150-154.

Balfas, R., \& Willis, M. (2009). Pengaruh ekstrak tanaman obat terhadap mortalitas dan kelangsungan hidup Spodoptera litura (Lepidoptera, Noctuidae). Bul. Littro., 20(2), 148-156.

Boi, M., Serra, G., Colombo, R., Lodesani, M., Massi, S., \& Costa, C. (2016). A 10 year survey of acariside residues in beeswax analysed in Italy. Pest Manag. Sci. 72: 1366-1372.

Budiwijono, T. (2012). Identifikasi produktifitas koloni lebah Apis mellifera melalui mortalitas dan luas eraman pupa di sarang pada daerah dengan ketinggian berbeda. Jurnal Gamma, $7(2), 111-123$.

Çobanoğlu, S., \& Tüze, Ș. (2008). Determination of amitraz (varroaset) in honey by High Permormance Liquid Chromatography (HPLC). Tarim Bilimleri Dergisi, 14(2), 169174.

Deletre, E., Martin, T., Campagne, P., Bourguet, D., Cadyn, A., Menut, C., Bonafos, R., \& Chandre, F. (2013). Reppelent, irritant, and toxic effects of 20 plant extracts on adults of the malaria Anopheles gambiae mosquito. PLOS one, 12(8),e82103, doi:10.1371/journal.pone. 0082103 .

Djiwanti, S.R., \& Wiratno. (2011). Evaluasi pemanfaatan formula pestisida nabati cengkeh dan serai wangi untuk pengendalian busuk rimpang jahe $>50 \%$. Di dalam Prosiding Seminar Nasional Pestisida Nabati IV Jakarta 15 Oktober 2011. Balai Penelitian Tanaman Rempah dan Obat, Bogor, 213-222.

El-Zemitry, S.R., Rezk, H.A., \& Zaitoon, A.A. (2006). Acaricidal activity of some eseential oils and their monotherpenoidal constituents against the parasitic mites, Varroa destructor (Acari: Varroidae). J. of Apllied Science Research, 2(11), 1032-1036.

Girisgin, A.O., Barel, S., Zilberman-Barzilai, D., \& Girisgin, O. (2014). Determining the stability of clove oil (eugenol) for use as an acaricide in beeswax. Israel J. of Veterinary Medicine, 69(4), 192-196.

Gonzáles-Cabrera, J., Rodriguez-Vargas, S., Davies, T.G.E., Field, L.M., Schmehl, D., Ellis, J.D., Krieger, K., \& Williamson, M.S. (2016). Novel mutations in the voltage-gated sodium channel of pyrethroid-resistant Varroa destructor populations from the southeastern USA. PLoS ONE, 11(5), e0155332. Doi:10.1371/ journal.pone. 0155332 .

Goswami, V., Srivastava, P., \& Khan, M.S. (2014). Efficacy of essential oils against Varroa destructor infesting Apis mellifera Linn. colonies and their impact on brood development. J. of Applied and Natural Science, 6(1), 27-34.

Handayani, T., Sakinah, S., Nallappan, L., \& Pihie, A.H.L. (2007). Regulation of p53-, Bcl-2-, and caspase-dependent signaling pathway in xanthorrizol-induced apoptosis of HepG2 hepatoma cells. Anticancer Research 27, 965972.

Hartati, S.Y. (2012). Prospek pengembangan minyak atsiri sebagai pestisida nabati. Perspektif 11(1): 45-58.

Histo, D.M., Utomo, E.P., \& Himawan, T. (2014). Kajian secara in silico terhadap potensi eugenol dan sitronelal sebagai pestisida nabati untuk pengendalian serangga Helopeltis antonii. Kimia Student J., 2(2), 562-568.

Howis, M., \& Nowakowski, P. (2009). Varroa destructor removal efficiency using bee vital hive clean preparation. J. of Apicultural Science, 35(2), 15-20.

Kampler, M., Nesvorma, M., Stara, J., Erban, T., \& Hubert, J. (2016). Comparison of taufluvalinate, acrinathrin, and amitraz effects on susceptible and resistance populations of Varroa destructor in a vial test. Experimental and Apllied Acarology, 69(1), 1-9.

Kumalasari, A.N. (2015). Analisis probit untuk menentukan pestisida nabati yang efektif bagi Crocidolamia pavonana. Thesis S1. Departemen Statistika, Fak. MIPA, IPB.

Kuntadi \& Andadari, L. (2013). Aktivitas akarisida beberapa minyak atsiri, insektisida nabati dan cuka kayu terhadap Varroa destructor Anderson \& Trueman. Jurnal Penelitian Hutan Tanaman, 10(1), 33-42.

Locke, B. (2012). Host-parasite adaptations and interaction between honey bees, varroa mites, and viruses. Doctoral Thesis. Swedish University of Agricultural Science, Uppsala, Sweden. 
Maggi, M., Ruffinengo, S., Damiani, N., Sardella, N., \& Eguaras, M. (2009). First detection of Varroa destructor resistance to coumaphos in Argentina. Experimental and Applied Acarology, 47, 317-320.

Maggi, M., Ruffinengo, S., Negri, P., \& Eguaras, M. (2010). Resistance phenomena to amitraz from populations of the ectopatasitic mite Varroa destructor of Argentina. Parasitology Research, 107, 1189-1192.

Mahmood, R., Asad, S., Raja, S., Mohsin, A.U., Wagchoure, E.S., Sarwar, G., Islam, N., \& Ahmad, W. (2014). Control of Varroa destructor (Acari: Varroidae) in Apis mellifera (Hymenoptera: Apidae) by using plant oils and extract. Pakstan J. Zool, 46(3), 609-615.

Martin, S.J., Highfield, A.C., Brettell, L., Villalobos, E.M., Budge, G.C., Powell, M., Nikaido, S., Schroeder, D.C. (2012). Global honey bee viral landscape altered by a parasitic mite. Science, 336, 1304-1306.

Medici, S.K., Castro, K., Sarlo, E.G., Marioli, J.M., \& Eguaras, M.J. (2012). The concentration effect of selected acaricides present in beeswax foundation on the survival of Apis mellifera colonies. J. of Apic. Res., 51(2), 164-168.

Ostiguy, N., \& Oitzer, B. (2014). Overwintered brood comb honey: colony exposure to pesticide residues. J. of Apicultural Research, 53(3), 413-421.

Qayyoum, M.A., Khan, B.S., \& Bashir, M.H. (2013). Efficacy of plant extracts against honey bee mite, Varroa destructor (Acari: Varroidae). World J. ofZoology 8(2), 2012-2016.

Rizal, M. (2009). Produk pestisida nabati berbasis minyak atsiri. Pusat Penelitian dan Pengembangan Perkebunan, Bogor. Info Tek Perkebunan, 1(12), 47.

Ruffinengo, S.R., Maggi, M.D., Fuselli, S., De Piano, F.G., Negri, P., Brasesco, C., Satta, A., Floris, I., \& Eguaras, M.J. (2014). Bioactivity of microencapsulated essentials oils and perspective of their use in the control of Varroa destructor. Bulletin of Insectology, 67(1), 8186.
Rukayadi, Y., Yong, D., \& Hwang, J.K. (2006). In vitro anticandidal activity of xanthorrizol isolated from Curcuma xanthorrhiza Rozb. J. of Antimicrobial Chemotherapy 57, 1231-1234.

Sundararajan, R., Bharampuram, A., \& Koduru, R. (2014). A review on phytoconstituents for nephroprotective activity. Pharmacophore 5(1), 160-182.

Widiarti, A. \& Kuntadi. (2012). Budidaya lebah madu Apis mellifera L. oleh masyarakat pedesaan di Kabupaten Pati-Jawa Tengah. Jurnal Penelitian Hutan dan Konservasi Alam, 4(4), 351361 .

Widyasari, R. (2006). Pengujian asam semut dan cuka kayu dalam pengendalian tungau (Varroa destructor) pada lebah madu (Apis mellifera). Skripsi S1. Program Studi Budidaya Hutan, Fakultas Kehutanan, IPB.

Wilis, M., Wiratno, \& Wahyuno, D. (2013). Efektivitas mulsa limbah atsiri dan pestisida nabati mengendalikan serangan Crocidolomia binotalis. Bul. Litrro, 24(2), 111-122.

Wilis, M. (2010). Formulasi pestisida nabati berbahan aktif eugenol, sitronela, sinamal-dehid, curcumin, dan xanthorizol yang efektif menekan Conopomorpha cramerella dan Helopeltis sp. Pada kakao (40-50\%) dan tidak membunuh musuh alami. Laporan akhir. Program Insentif Riset Terapan, Balai Penelitian Tanaman Obat dan Aromatik, Pusat Penelitian dan Pengembangan Perkebunan, Bogor.

Wiratno. (2008). Effectiveness and safety of botanical pesticides applied in black pepper (Piper nigrum) plantations. Doctoral Thesis. Wageningen University, Wageningen, Netherlands.

Wiratno. (2011). Efektifitas pestisida nabati berbasis minyak jarak pagar, cengkeh dan serai wangi terhadap mortalitas Nilaparvata lugens Stahl. Di dalam Prosiding Seminar Nasional Pestisida Nabati IV Jakarta 15 Oktober 2011. Balai Penelitian Tanaman Rempah dan Obat, Bogor, 19-28.

Zoubiri, S., \& Baaliouamer, A. (2014). Potentiality of plants as a source of insecticide principles. J. of Saudi Chem. Soc., 18, 925-938. 